\title{
DELAY EFFECT OF MUD LOADING TO THE OPEN PIT DESIGN IN TERMS OF MEETING 2018 - A COAL PRODUCTION TARGET CASE STUDY OF PIT XYZ AT SOUTH KALIMANTAN
}

\author{
PENGARUH KETERLAMBATAN PEMUATAN LUMPUR \\ TERHADAP RANCANGAN PENAMBANGAN DALAM RANGKA \\ MEMENUHI TARGET PRODUKSI BATUBARA 2018 SEBUAH \\ STUDI KASUS DI PIT XYZ, KALIMANTAN SELATAN
}

\author{
KAREL L. WARDA, BAGUS WIYONO, TEDY A. CAHYADI and SIGIT B. PRABOWO \\ UPN "Veteran" Yogyakarta, Department of Mining Engineering \\ Jalan SWK Jalan Ring Road Utara No.104, Ngropoh, \\ Condongcatur, Daerah Istimewa Yogyakarta 55283 \\ e-mail: karellutanwarda@gmail.com
}

\begin{abstract}
Based on the 2018, there a mining plan, two temporary sumps, namely the ABC and BCD sumps. They located in a mining sequence pattern. These sumps required a mud loading process prior to mining the coal below the sequence. The mud loading process is loaded sequentialy. However, the problem occurs when the mud loading process in the ABC sump is delayed, and resulted only $42 \%$ of mud production. Such the delay resulted in hindering the mining sequence pattern which forced changes in plans, designs, and decrease of coal production. These condition led to study the cause, impact, and alternative solution of the delay during mud loading process. The method used in this study includes direct observations and data collection of working conditions, equipment capabilities, material properties, and operation timeline. In this study, the statistical analysis is used to determine the cause and effect of delayed mud loading process. A Minex Software is then used to simulate the alternative of redesign the mining sequence pattern. The study found that the delay in mud loading process is due to the external and internal factors, that result in underproduction of coal only 505,833 tons, and delayed of coal production around 64 days. An alternative that can be conducted is to change the direction progress to the area that has low stripping ratio. Factors that can hinder the progress are need to be considered for anticipating the plan distraction at mid-term-plan.
\end{abstract}

Keywords: delay, mud loading, sequence, coal production.

\begin{abstract}
ABSTRAK
Pada rencana penambangan 2018, terdapat dua lopak sementara yang terletak pada kemajuan urutan penambangan, yaitu lopak $A B C$ dan $B C D$. Kedua lopak tersebut memerlukan proses pemuatan lumpur sebelum batubara pada urutan tersebut dapat ditambang. Kegiatan pemuatan lumpur pada kedua lopak akan dilakukan secara berurutan. Permasalahan terjadi ketika pemuatan lumpur pada lopak $A B C$ mengalami keterlambatan yang mengakibatkan pencapaian target produksi lumpur hanya sebesar $42 \%$. Keterlambatan tersebut menghambat kemajuan urutan penambangan, sehingga terjadi perubahan rencana, rancangan serta turunnya pencapaian produksi batubara. Kondisi tersebut memerlukan kajian terhadap penyebab, dampak, dan alternatif penyelesaian keterlambatan. Metode penelitian ini dilakukan berdasarkan pengamatan dan pengambilan data secara langsung terhadap kondisi kerja, kemampuan alat, sifat material, dan waktu operasi. Analisis dilakukan secara statistik dan analitik untuk menentukan penyebab keterlambatan dan dampak yang ditimbulkan. Perubahan rancangan pada software Minex digunakan sebagai alternatif simulasi kemajuan urutan penambangan untuk dapat mencapai target produksi batubara. Ketidaktercapaian produksi lumpur terjadi karena faktor eksternal dan internal, sehingga mengakibatkan keterlambatan selama 64 hari, dan ketidaktercapaian produksi batubara
\end{abstract}


sebesar 505.833 ton. Alternatif yang dapat dilakukan adalah mengubah arah kemajuan ke wilayah nisbah pengupasan rendah. Pertimbangan terhadap faktor yang dapat menghambat kemajuan urutan sangat perlu dipertimbangkan agar tidak mengganggu perencanaan jangka menengah.

Kata kunci: keterlambatan, mud loading, urutan, produksi batubara

\section{INTRODUCTION}

In mining industry, the process of mine planning aims to determine the order and method of mining minerals (Blom et al., 2016). Mine planning and design are needed as the basis for realistic and actionable decision making for the implementation in utilizing profitable mineral resources (Hustrulid, Kuchta and Martin, 2013). Adequate planning is very important to achieve the optimal outcome of mining operations (Caccettta and Hill, 1999). The process needs flexibility as measures to unexpected changes in production activities, and made timely assessments and adjustments (Darling, 2011). The short-term planning is more geared toward achieving a goal in a time scale ranging from day-to-day planning to multiple-year production plans, Long-term planning is more concerned with providing frameworks for pit design and expansions (pushbacks), production schedules, and equipment selection, whereas short-term planning focuses on equipment usage, maximize productivity, and meet productions targets (Darling, 2011). One of the classic problems in the mining industry in open pit mining is the constraint in production scheduling (Lambert et al., 2014).

To conduct mining activities, PT. Al the in Tabalong Regency, South Kalimantan Province faced challenges in the mining sequence progress. The plan of the west high wall area, XYZ Pit, where the two sump intermediates, $A B C$ and $B C D$ sump, is located in the 2018 mining sequence progress. Mining activities can be carried out in the area after the sumps require mud loading process. Mud loading process defined as a mud transfer activity to simplify coal mining activities under mud material (Zaki, 2018). In the 2018 mining plan, the mud loading process will be carried out sequentially, starting with the $A B C$ sump containing 955,062 bank cubic meter (BCM) with a work schedule in March-April 2018, and then BCD sump with a volume of $598,850 \mathrm{BCM}$ with a work schedule in May 2018.
In March 2018, the mud loading process in the $A B C$ sump was delayed, and resulted only $42 \%$ of mud production target. The delay in mud loading on $A B C$ sump could affect the completion of mud loading in BCD sump. The delay directly hindered the mining sequence progress which resulted in underachievement of coal production targets in the west high wall area. The delay in mud loading process resulted in unachieved coal production targets around 554,113 tons in 2017 . In relation to the delay, a study is needed to understand the causes and impacts, while at the same time provides alternative to the mud loading process so the production target in 2018 can be achieved.

\section{METHOD}

Observin the mud loading process in the $A B C$ sump is used as the research method in this study. The data were collected in March 2018 based on their primary and secondary characteristics. The primary data consists of the distribution time of transport and loading equipment, swell factor value of mud, mud volume, and hauling distance, while the secondary data used in this study are the calendar time, value of physical availability plan, rainfall, solid mud percentage, production plan, excessive work time loss in March 2018, and value of California Bearing Ratio (CBR) haul road, swell factor value of cover soil layer material and coal, as well as official draft maps in 2018.

The data were processed with statistical and non-statistical calculations to obtain causes, impacts, and alternatives to the plan and design. The mining sequence simulation model was processed by using Minex software. A Simulation was performed to determine the amount of coal that can be produced until the end of 2018. The simulation was carried out until the cover soil layer production criteria were $>32,361,694$ $\mathrm{BCM}$ and coal $>4,358,990 \mathrm{BCM}$, with $\pm 1 \%$ deviation. 


\section{RESULTS AND DISCUSSION}

\section{Intermediate Sump Mud Volume}

The volume of mud in the intermediate sump (Table 1) was based on its type and divided into two categories, namely wet mud volume and solid mud volume. In general, the wet mud is a mud produced by the deposition process of solid material granules carried by water from open channels, while the solid mud is a mud formed by in-situ material around the sump which affected by the water content in the sump.

Table 1. Mud volume

\begin{tabular}{lccc}
\hline Parameter & Unit & Sump ABC & Sump BCD \\
\hline $\begin{array}{l}\text { Wet Mud } \\
\text { Volume }\end{array}$ & BCM & 505.770 & 323.200 \\
$\begin{array}{l}\text { Solid Mud } \\
\text { Volume }\end{array}$ & BCM & 449.292 & 275.650 \\
\hline Total & BCM & 955.062 & 598.850 \\
\hline
\end{tabular}

\section{Properties of Intermediate Sump Mud}

Based on the measurement results of mud material in March 2018, the mud had a solid percentage of $36-60 \%$ during the mud loading process in ABC sump, with density of 1.495 tons $/ \mathrm{m}^{3}$ and swell factor of 0.9076 . Differences were found between this value and initial value of assumptions at the planning stage, which is solid percentage of $40-55 \%$, density of 1.41 tons $/ \mathrm{m}^{3}$, and swell factor of 1 .

\section{Loading Pattern}

The loading pattern in the mud loading process of the ABC sump is a combination of loading process by two equipments between Hitachi EX 2500 backhoe and Hitachi EX 2500-6 shovel with hauling equipment, Komatsu HD 785 tailgate and non-tailgate, which used single-side and bottom loading technique with the frontal cut loading position.

\section{Dumping Distance}

In the planning process, dumping activities were carried out in High wall 1 mud disposal with a distance of $3.5 \mathrm{~km}$ from $A B C$ sump, and $4.9 \mathrm{~km}$ from BCD sump. The dumping distance was changed before the mud loading process was carried out. There were geotechnical problems in High wall 1 mud disposal, which led to changes in the dumping process in High wall 3 mud disposal. The change resulted in an increase of hauling distance to $5.5 \mathrm{~km}$ from the $A B C$ sump and $7.6 \mathrm{~km}$ from the BCD sump.

\section{Loader and Hauler Cycle Time}

Table 2 presents the cycle time of mechanical equipment in the mud loading process. Hitachi EX-2500-6 shovels and Hitachi EX2500 backhoe have a slower distribution of time. At the planning stage, the loading cycle time is 0.516 minutes, while the actual cycle time is 0.54 minutes. This problem also happened in hauling cycle time of dump truck Komatsu HD 785. During the hauling cycle, there was an increase of 16.8 minutes compared to the plan. At the planning stage hauling cycle time is $\mathbf{2 5 . 9}$ minutes, while the actual hauling cycle time condition is 42.7 minutes. Increasing cycle time is the impact of distance change.

Table 2. Cycle time mechanical equipment

\begin{tabular}{llc}
\hline No. & \multicolumn{1}{c}{ Equipment Types } & $\begin{array}{c}\text { Cycle Time } \\
\text { (minutes) }\end{array}$ \\
\hline 1. & Shovel Hitachi EX2500-6 & 0.54 \\
2. & Backhoe Hitachi EX2500 & 0.587 \\
3. & $\begin{array}{l}\text { Dump Truck Komatsu } \\
\text { HD785-7 }\end{array}$ & 42.7 \\
\hline
\end{tabular}

\section{Hauling Road}

Faulty road design also influence the production performance of the hauler (Mkhatsahwa, 2009) Figure 1 is an overview of hauling road from sump intermediate to the mud pond which used in the mud loading process (Disposal High wall 3). The hauling road had no narrow road or excessive sloppy road, but few road conditions were undulated. The undulation was found at the location marked with a blue circle. The undulated hauling road could disrupt the hauling process and the speed of hauling truck.

\section{Match Factor}

A mine ideal standard was developed to compare actual results against a targeted mine potential (Pasch and Uludag, 2018). The determination of working match the value of the mechanical equipment used during production process is based on the haulingloading cycle and the number of hauling and loading equipment. The variety of hauling and 
loading equipment also influences the compatibility between the equipment (Burt and Caccetta, 2018). The Hitachi EX2500-6 shovel with $15 \mathrm{~m}^{3}$ bucket capacity and Hitachi EX2500 backhoe with $13.8 \mathrm{~m}^{3}$ bucket capacity is used for mud loading process. The two loading equipment were combined with nineteen HD785-7 tailgate dump trucks and seven HD785-7 non-tailgate dump trucks. According to Burt and Caccetta (2018), the mechanical equipment is compatible for the mud loading process which include loading equipment and hauling equipment that are heterogenic. Based on the observatory data, the equipment work match factor is 0.6817 . In the real condition, the loading equipment waited for the hauling equipment and vice versa.

\section{Excessive Working Time Loss}

Various factors have affected the length of time-loss during the mud loading process. The findings in actual condition shows that the loss of working time exceeds over the planned time. The collected data for 31 days in March 2018 shows that several factors were caused excess standby hours, pause hours and operating delay hours. The following is a comparison of actual conditions and planned working time loss on a rainy weather, slippery condition, praying, and toilet stops, refueling, light maintenance of heavy equipment, waiting time (use of availability), and front/road/ disposal preparations.
On the loading equipment, excess losses in working time of March 2018 described as follows:

- Stand-by hours: due to rainy weather for 45.2 hours, and slippery road condition for 11 hours;

- Pause hours: praying and toilet break for 3.1 hours;

- Operating delay hours: due to refueling for 1.2 hours, light maintenance for 1.3 hours, waiting time for 114.8 hours, and front/ road/disposal preparations for 1 hour.

Figure 2 shows the percentage of each factor leading to working time loss on the loading equipment in March 2018.

On the hauling equipment, there were excessive working time losses in March 2018 as follows:

- Stand-by hours: due to rainy weather for 75.2 hours, and slippery for 10.8 hours;

- Pause hours: praying and toilet break for 3.15 hours;

- Operating delay hours: due to refueling for 2.5 hours, light maintenance of the equipment for 42 minutes, waiting time for 11.1 hours, and front/road/disposal preparations for 24 minutes.

The following is the percentage of each factor leading to excessive working time losses on the hauling equipment in March (Figure 3).

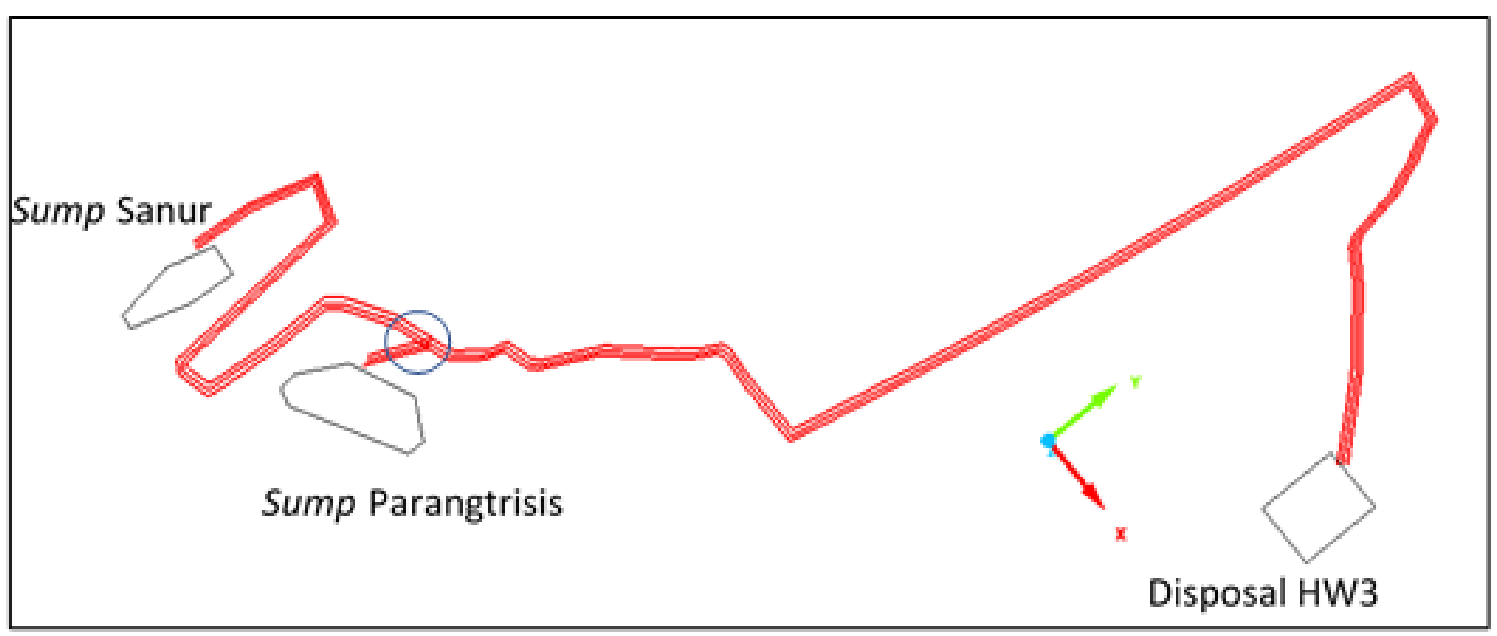

Figure 1. Hauling road (not to scale) 


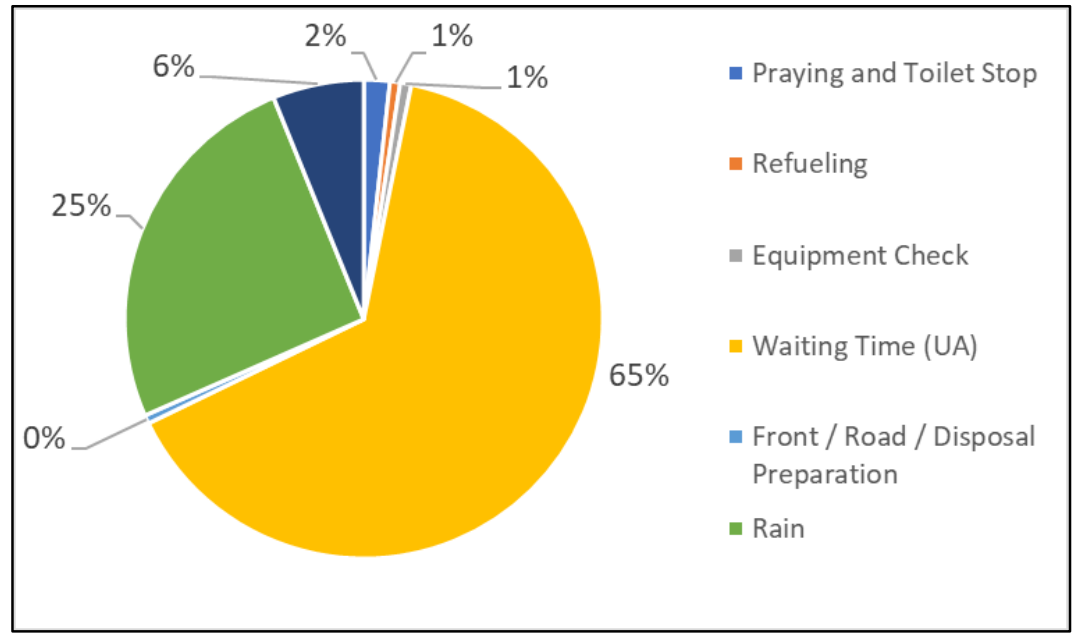

Figure 2. The percentage of each factor leading to excessive working time loss on loading equipment

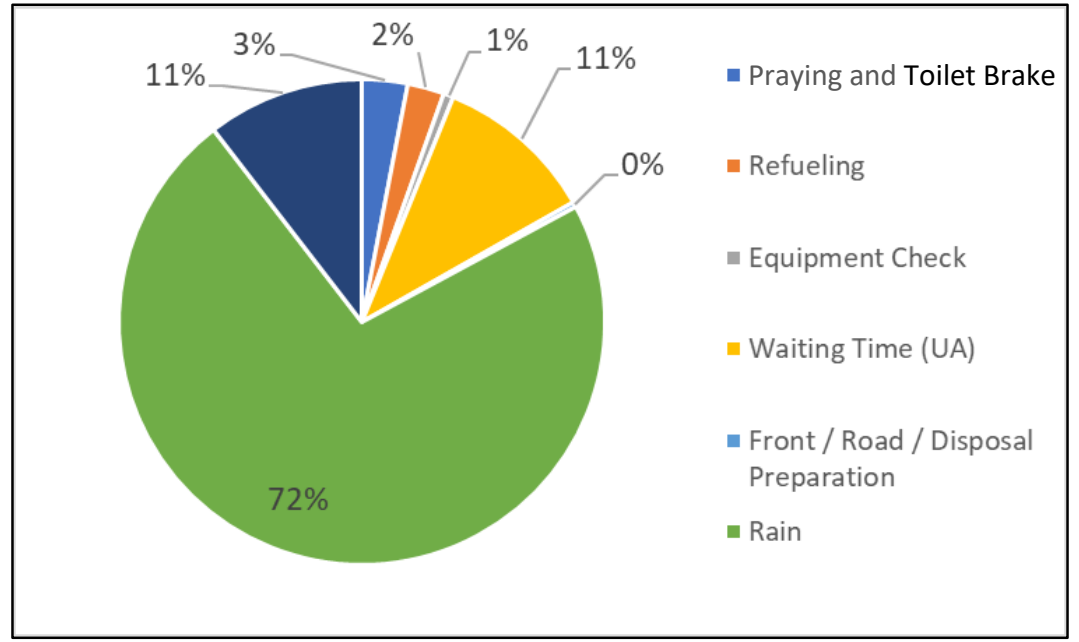

Figure 3. The percentage of each factor leading to excessive working time loss on the hauling equipment

\section{Working Time, Equipment Availability and Utilization}

One of the major problems in production for an open pit mine is caused by a large number of factors (Manyele, 2017). The availability and usage factor of the equipment (Hustrulid, Kuchta and Martin, 2013) is used to determine equipment efficiency and time effectiveness, Table 3 shows the working time and availability of the mud loading process equipment in March 2018.

\section{Mud Loading Production in March 2018}

The mud loading production is calculated based on loading equipment productivity and actual loading calendar time, with the consideration from equipment performance data per March 2018. Total mud production during March was $258,409.6$ BCM or $42 \%$ of $620,134.7$ BCM from predetermined production target. The decrease in production was influenced by the different assumptions of swell factor of $9.24 \%$, less optimal loading cycle of $7.77 \%$, and the effect availability and utilization of equipment were $41.33 \%$. Figure 4 presents the effect of production factors which decrease mud production in March 2018, while Figure 5 shows the influence of the value of availability and use of the equipment and operating delay hours factor on production achievement. 


\section{Improvement of Equipment Cycle Time}

Based on the loading cycle, the EX 2500 backhoe had a longer loading time compared to the EX 2500-6 shovel due to bottom loading position. Bottom loading patterns are appropriate to use based on consideration to the mud loading fronts. Improvements could be made to single-side loading patterns and frontal cut techniques. Both methods were used based on consideration to the working area and the potential of sudden occurrence in the mud.
Table 3. Working time and equipment availability factors

\begin{tabular}{lcc}
\hline \multicolumn{1}{c}{ Parameters } & Loader & Hauler \\
\hline Total Hours(Hours) & 744 & 744 \\
Up Time (Hours) & 658 & 658 \\
Working Hours (Hours) & 441 & 411 \\
Operating Hours(Hours) & 333 & 305 \\
Efficiency Hours(Hours) & 185 & 261 \\
PA (\%) & 88.44 & 88.44 \\
UA (\%) & 67 & 62.46 \\
WE (\%) & 75.64 & 74.27 \\
JE (\%) & 55.57 & 85.44 \\
\hline
\end{tabular}

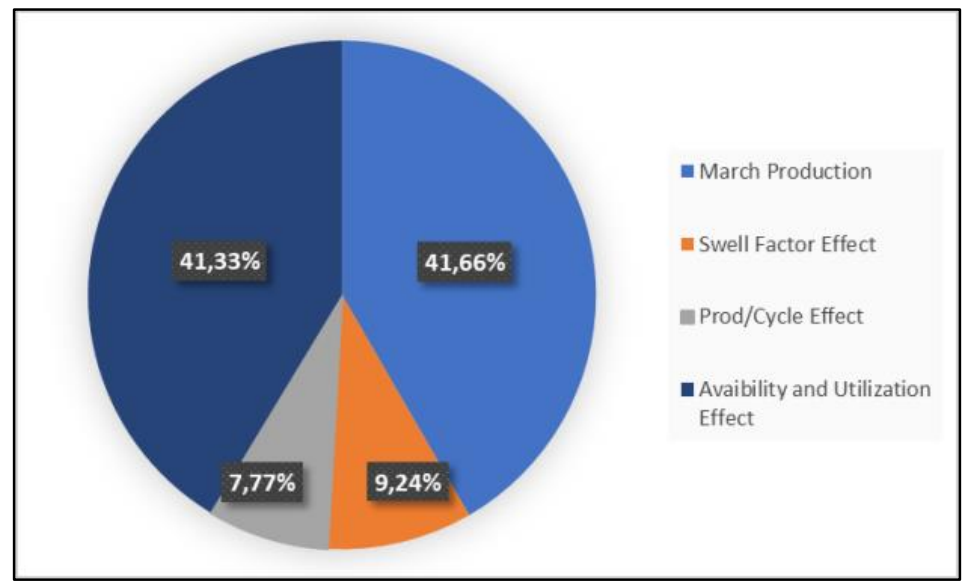

Figure 4. Effect of production factors on production achievement

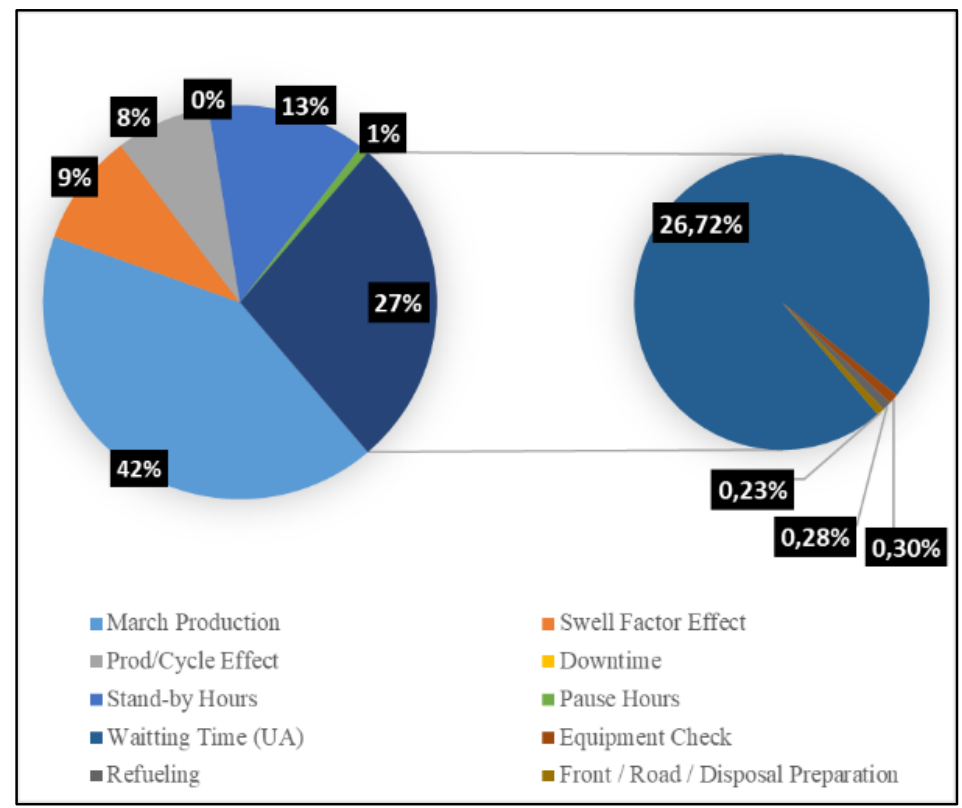

Figure 5. Value influence of availability and use of equipment and operating delay hours factor on production achievement 
Based on observations at the end of March 2018 , there was a queue of hauling equipment and an increase of workload in the working area. This was a consideration for double-side loading. The usage of frontal cut technique was less effective on the side of swing angle of loading equipment, which could be fixed by a parallel cut technique. The parallel cut could be used by the operator with visual consideration to the mud condition. The actual condition show inefficiency because the delay in the hauling equipment, as the use of $T$ pattern when positioning the hauling equipment, faced with undulated road conditions. Efforts to optimize the time used in hauling equipment were made by conducting synchronization on hauling equipment, using double-side loading, $Y$ pattern positioning, and provide support to equipment management, especially towards improvement to the road used to haul. (Caterpillar, 2013) On the other hand, the use of a tailgate hauling equipment could increase productivity. As shown in Tables 4, 5, and 6 show the time improvement that was calculated using the mode value of processing in loading and hauling cycle.

Table 4. EX 2500-6 shovel loading cycle time

\begin{tabular}{cccc}
\hline \multirow{2}{*}{ No. } & \multirow{2}{*}{ Activities } & \multicolumn{2}{c}{$\begin{array}{c}\text { Cycle Time } \\
\text { (seconds) }\end{array}$} \\
\cline { 3 - 4 } & & Before & After \\
\hline 1 & Digging Time & 11 & 1 \\
2 & Swing Time (fill) & 9.5 & 2 \\
3 & Dumping Time & 5.1 & 3 \\
4 & Swing Time (empty) & 6.8 & 4 \\
\hline Total (Seconds) & 32.4 & 29.3 \\
\hline Minutes & 0.54 & 0.488 \\
\hline
\end{tabular}

Table 5. EX 2500 backhoe loading cycle time

\begin{tabular}{cccc}
\hline \multirow{2}{*}{ No. } & \multirow{2}{*}{ Activities } & \multicolumn{2}{c}{$\begin{array}{c}\text { Cycle Time } \\
\text { (seconds) }\end{array}$} \\
\cline { 3 - 4 } & & Before & After \\
\hline 1 & Digging Time & 12 & 1 \\
2 & Swing Time (fill) & 10.2 & 2 \\
3 & Dumping Time & 5.6 & 3 \\
4 & Swing Time (empty) & 7.4 & 4 \\
\hline Total (Seconds) & 35.2 & 32.1 \\
\hline Minutes & 0.587 & 0.535 \\
\hline
\end{tabular}

Table 6. HD 785-7 hauling cycle time

\begin{tabular}{clcc}
\hline \multirow{2}{*}{ No. } & \multicolumn{1}{c}{ Activities } & \multicolumn{2}{c}{$\begin{array}{c}\text { Cycle Time } \\
\text { (seconds) }\end{array}$} \\
\cline { 3 - 4 } & & Before & After \\
\hline 1 & Waiting time for & 173.5 & 1 \\
& loading & 35 & 2 \\
2 & Positioning time & 153.5 & 3 \\
3 & Loading time & 1127.6 & 4 \\
4 & Hauling time & 25.4 & 5 \\
5 & Waiting time for & 23.4 & 6 \\
& dumping & 52.7 & 7 \\
6 & Positioning time & 971.1 & 8 \\
7 & Dumping time & $2,562.4$ & $2,459.60$ \\
8 & Empty loading time & 42.7 & 40.91 \\
\hline Total (Seconds) & \multicolumn{2}{c}{} \\
\hline Minutes &
\end{tabular}

\section{Improvement to Prevent Loss in Working Time}

The excessive loss of working time occurred due to various factors. Some of the factors that could be corrected were the time of delay due to praying and toilet breaks $(A)$, refueling $(B)$, light maintenance of heavy equipment (C), UA waiting time $(D)$, and front/road/disposal preparations $(E)$. Improvements were made by informing on delays due to praying and toilet breaks towards the relevant departments, managing the arrival of fuel tanks and refueling queues, carrying out light maintenance activities according to the SOP, implementing a tool synchronization system, and managing support equipment so that the loading and hauling processes were not disturbed.

Using the mode value for excessive working time loss, the time value could be optimized (Tables 7 and 8). These values were then calculated to find the value of improvement factors. The improvement factors in Tables 9 and 10 were used as correction for calendar time and measures to rescheduling the plan. The calculations were carried out on the loading and hauling equipment calendars. Table 11 shows changes in calendar time before and after correction to the excessive working time loss. 
INDONESIAN MINING JOURNAL Vol. 23, No. 2, October $2020: 67$ - 82

Table 7. Optimization of excessive working time loss in loading equipment

\begin{tabular}{lccccc}
\hline \multirow{2}{*}{ Descriptions } & \multicolumn{4}{c}{ Pause Hours } & \multicolumn{4}{c}{ Operating delay Hours } \\
\cline { 2 - 6 } & $\mathrm{A}$ & $\mathrm{B}$ & $\mathrm{C}$ & $\mathrm{D}$ & $\mathrm{E}$ \\
\hline Average (minutes/days) & 6.61 & 2.85 & 4.74 & 222.86 & 3.18 \\
Mode (minutes/days) & 4.42 & 1.14 & 2.69 & 234.16 & 1.5 \\
Optimization of Time Loss (minutes/days) & 4.42 & 1.14 & 2.69 & 222.86 & 1.5 \\
Optimization of Time Loss(hours/months) & 2.3 & 0.6 & 1.4 & 115.1 & 0.8 \\
\hline
\end{tabular}

Table 8. Optimization of excessive working time loss in hauling equipment

\begin{tabular}{lccccc}
\hline \multirow{2}{*}{ Descriptions } & Pause Hours & \multicolumn{4}{c}{ Operating delay Hours } \\
\cline { 2 - 6 } & $\mathrm{A}$ & $\mathrm{B}$ & $\mathrm{C}$ & $\mathrm{D}$ & $\mathrm{E}$ \\
\hline Average (minutes/days) & 5.95 & 5.36 & 2.63 & 21.66 & 1.50 \\
Mode (minutes/days) & 2.73 & 4.26 & 3.58 & 21.54 & 2.4 \\
Optimization of Time Loss (minutes/days) & 2.73 & 4.26 & 2.63 & 21.54 & 1.50 \\
Optimization of Time Loss(hours/months) & 1.4 & 2.2 & 1.4 & 11.1 & 0.8 \\
\hline
\end{tabular}

Table 9. Improvement factors of excessive working time loss in the loading equipment

\begin{tabular}{lccccc}
\hline \multicolumn{1}{c}{ Descriptions } & Pause Hours & \multicolumn{3}{c}{ Operating delay Hours } \\
\cline { 2 - 6 } & $\mathrm{A}$ & $\mathrm{B}$ & $\mathrm{C}$ & $\mathrm{D}$ & $\mathrm{E}$ \\
\hline Planned Time Loss (hours/months) & 22 & 3 & 2 & 13 & 6 \\
Optimization of Time Loss (hours/months) & 2.3 & 0.6 & 1.4 & 115.1 & 0.8 \\
Improvement Factors & 0.10 & 0.20 & 0.69 & 8.86 & 0.13 \\
\hline
\end{tabular}

Table 10. Improvement factors of excessive working time loss in the hauling equipment

\begin{tabular}{lccccc}
\hline \multirow{2}{*}{ Descriptions } & \multicolumn{4}{c}{ Operating delay hours } \\
\cline { 2 - 5 } & $\mathrm{A}$ & $\mathrm{B}$ & $\mathrm{C}$ & $\mathrm{D}$ & $\mathrm{E}$ \\
\hline Planned Time Loss (hours/months) & 22 & 3 & 2 & 13 & 6 \\
Optimization of Time Loss (hours/months) & 1.4 & 2.2 & 1.4 & 11.1 & 0.8 \\
Improvement Factors & 0.06 & 0.73 & 0.68 & 0.86 & 0.13 \\
\hline
\end{tabular}

Table 11. Improvement of mud loading process calendar time of 2018

\begin{tabular}{|c|c|c|c|c|c|c|c|c|c|c|}
\hline \multirow{2}{*}{ Parameters } & \multicolumn{2}{|c|}{ April } & \multicolumn{2}{|c|}{ May } & \multicolumn{2}{|c|}{ June } & \multicolumn{2}{|c|}{ July } & \multicolumn{2}{|c|}{ August } \\
\hline & Before & After & Before & After & Before & After & Before & After & Before & After \\
\hline $\begin{array}{l}\text { Total Hours } \\
\text { (Hours) }\end{array}$ & 720 & 720 & 744 & 744 & 720 & 720 & 744 & 744 & 744 & 744 \\
\hline $\begin{array}{l}\text { Up Time } \\
\text { (Hours) }\end{array}$ & 637 & 637 & 658 & 658 & 637 & 637 & 658 & 658 & 658 & 658 \\
\hline $\begin{array}{l}\text { Working } \\
\text { Hours } \\
\text { (Hours) }\end{array}$ & 473 & 473 & 572 & 572 & 510 & 510 & 598 & 598 & 554 & 554 \\
\hline $\begin{array}{l}\text { Operating } \\
\text { Hours } \\
\text { (Hours) }\end{array}$ & 371 & 369.73 & 452 & 451.03 & 401 & 399.79 & 494 & 492.97 & 455 & 454.03 \\
\hline $\begin{array}{l}\text { Efficiency } \\
\text { Hours } \\
\text { (Hours) }\end{array}$ & 346 & 331.46 & 427 & 412.77 & 371 & 352.25 & 469 & 454.7 & 428 & 412.06 \\
\hline PA (\%) & $88.50 \%$ & $88.50 \%$ & $88.50 \%$ & $88.50 \%$ & $88.50 \%$ & $88.50 \%$ & $88.50 \%$ & $88.50 \%$ & $88.50 \%$ & $88.50 \%$ \\
\hline UA (\%) & $74.26 \%$ & $74.26 \%$ & $86.94 \%$ & $86.94 \%$ & $80.07 \%$ & $80.07 \%$ & $90.89 \%$ & $90.89 \%$ & $84.21 \%$ & $84.21 \%$ \\
\hline WE (\%) & $78.44 \%$ & $78.13 \%$ & $79.04 \%$ & $78.79 \%$ & $78.64 \%$ & $78.36 \%$ & $82.62 \%$ & $82.38 \%$ & $82.14 \%$ & $81.89 \%$ \\
\hline JE (\%) & $93.27 \%$ & $89.65 \%$ & $94.47 \%$ & $91.52 \%$ & $92.52 \%$ & $88.11 \%$ & $94.94 \%$ & $92.24 \%$ & $94.07 \%$ & $90.76 \%$ \\
\hline
\end{tabular}




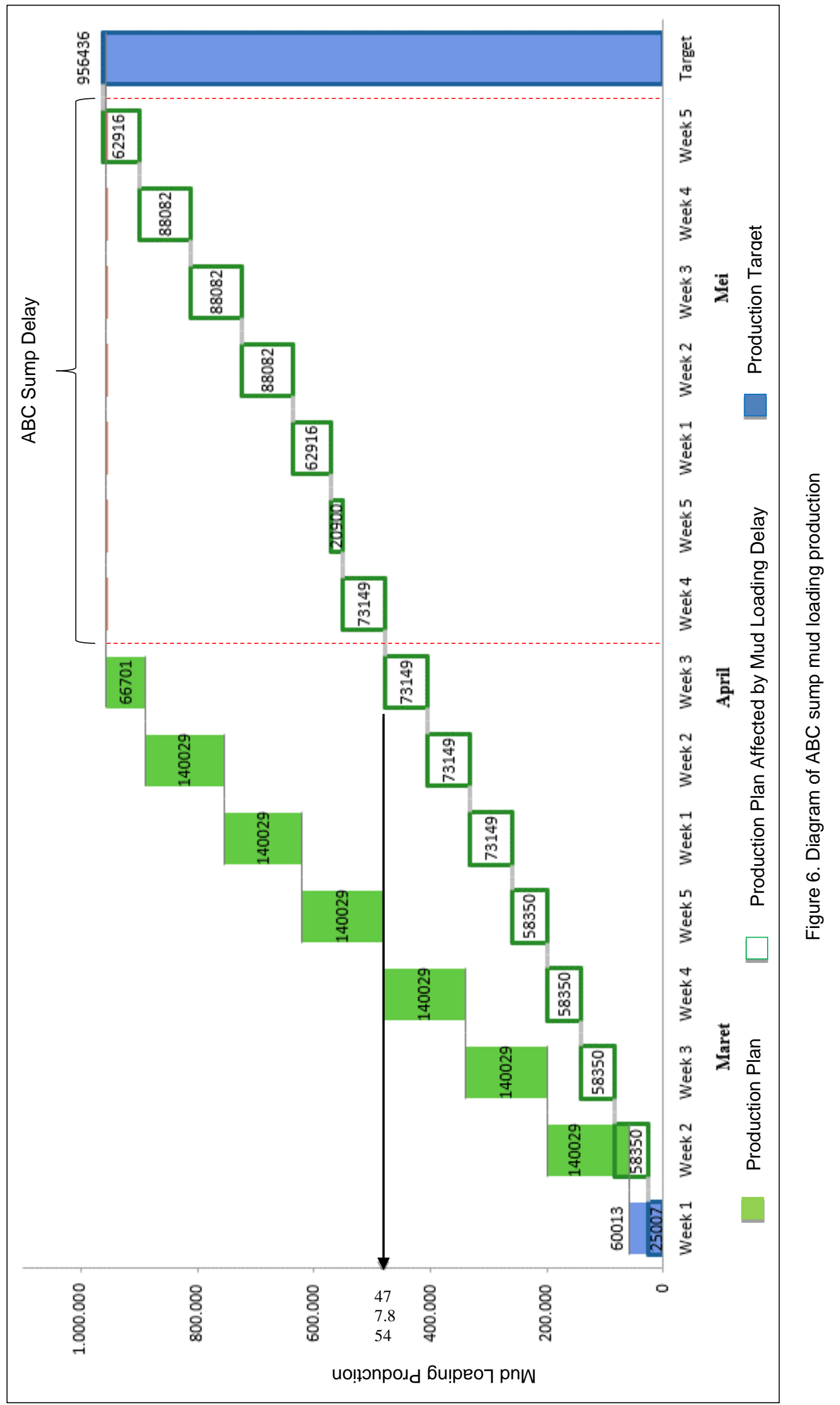




\section{Intermediate Sump Mud Loading Settlement}

Based on match factor with MF value = 0.6817, with the condition that loading equipment was delayed caused by unoptimized hauling equipment and loading capability, it is necessary to reschedule the mud loading completion process.

The hauling equipment productivity (Caterpillar, 2017) on ABC sump loading process was 317.4 BCM/Hour in March 2018, 435.03 BCM/Hour in April 2018, and 524.24 $\mathrm{BCM} /$ Hour in May 2018, it was estimated that ABC sump mud loading process will be completed in the fifth week of May 2018, precisely on May 31, 2018 (Figure 6). The hauling capability of BCD sump mud loading process was $348.2 \mathrm{BCM} /$ hour in June 2018, 434.9 BCM/hour in July 2018, and 394.13 $\mathrm{BCM} /$ hour in August 2018, it could be estimated that BCD sump mud loading process will complete in the first week of August, precisely on August 3, 2018 (Figure 7).

\section{Changes in the Needs of West High Wall Production Equipment}

In the last decade, uncertainty in the process of strategic mine planning has been a major discussion especially towards affirmation of strategic decisions, such as deciding the sequence of mining, investing in equipment fleet, and determining production per period with calculation to the uncertainty during the process (Nelis, Morales and WidzykCapehart, 2019). Mine planning and scheduling have a great impact for optimal mine exploitation (Ibrahimov et al., 2014). Table 1c shows the number of loading equipment used for cover soil loading in April to December 2018 plan. The production capacity of loading equipment in Table 12 is 32,361,694 BCM.

The equipment priority had changed due to the delay in mud loading process, as it hindered the sequence progress on the south side of west high wall. The number and type of loading equipment were changed by considering production capacity, working area, and road density on the west side. Three Hitachi EX2500 and one Komatsu PC 1250 were changed into two Komatsu PC 4000. The changes in loading equipment can be seen in Table 13.

The capacity of loading equipment production had change into $32,286,556 \mathrm{BCM}$. There was a difference in production capacity after undergoing changes in loading equipment of $75,138 \mathrm{BCM}$, but this was still within $\pm 1 \%$ tolerance.

\section{Minimum Width of Mining Front}

The consideration of to the movement capacity which associated with real equipment allows planner to obtain the plan that well-adjusted to real situation in the mining operation compared to defining movement per daily basis (González and Morales, 2019). In the design of west high wall in 2018, the minimum width of the mining front is calculated based on the combination of the largest loading and hauling equipment; Hitachi EX-2500 and Komatsu HD 785-7. The largest loading equipment, Hitachi EX-2500 to PC4000. The changes were needed to adjust with minimum width of mining front, so that production activities could run smoothly. The PC4000 loading equipment was combined with a hauling equipment namely Komatsu HD 1500-7 to avoid the density of the road on the west side.

The HD1500-7 hauling equipment has a larger dimension than HD 785-7, so that the minimum width of mining front could accommodate the combination of PC 4000 and Komatsu HD 1500-7 as Komatsu loading equipment was $34 \mathrm{~m}$.

\section{Hauling Road Construction Design}

The biggest change in loading equipment operating in west high wall area, namely Komatsu HD 785-7 to Komatsu HD 1500-7, would significantly affect the design in hauling road construction. Hauling road construction was calculated based on CBR value, with Thompson's formula (Thompson, 2015). The before and after change layers can be seen in Tables 14 and 15. 


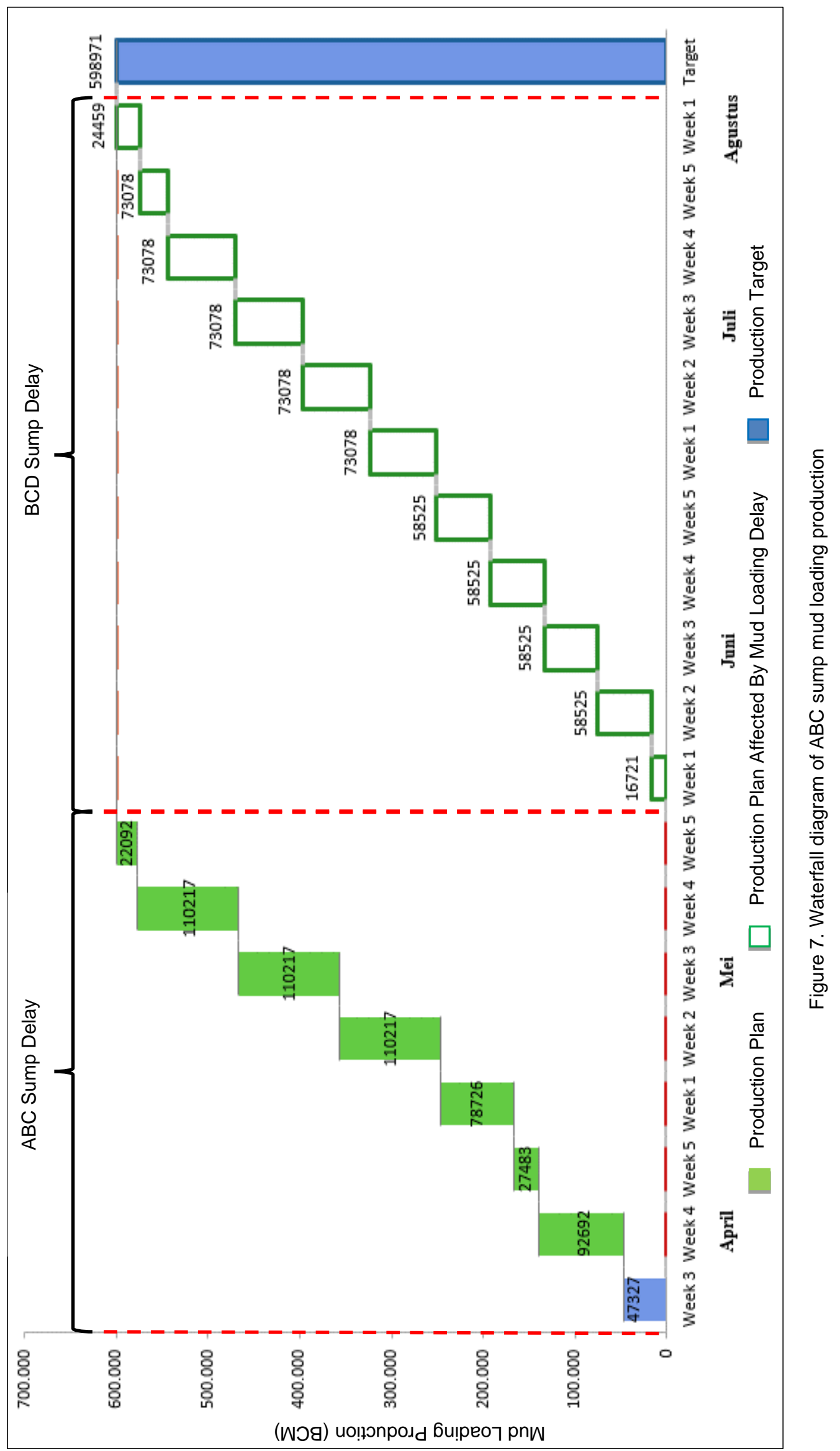


INDONESIAN MINING JOURNAL Vol. 23, No. 2, October 2020 : 67 - 82

Table 12. Types and number of West High wall equipment before changes

\begin{tabular}{lccccccccc}
\hline \multirow{2}{*}{ Equipments } & \multicolumn{8}{c}{ Number of equipment } \\
\cline { 2 - 10 } & Apr & Mei & Jun & Jul & Aug & Sept & Oct & Nov & Dec \\
\hline Hitachi EX-2500 & 9 & 9 & 9 & 9 & 9 & 10 & 10 & 10 & 10 \\
Komatsu PC2000 & 0 & 0 & 0 & 0 & 0 & 1 & 1 & 1 & 1 \\
Komatsu PC1250 & 2 & 2 & 2 & 2 & 2 & 2 & 2 & 2 & 2 \\
\hline
\end{tabular}

Table13. Types and number of West High wall equipment after changes

\begin{tabular}{cccccccccc}
\hline \multirow{2}{*}{ Equipment } & \multicolumn{8}{c}{ Number of equipment } \\
\cline { 2 - 10 } & Apr & Mei & Jun & Jul & Aug & Sept & Oct & Nov & Dec \\
\hline Hitachi EX-2500 & 6 & 6 & 6 & 6 & 6 & 7 & 7 & 7 & 7 \\
KomatsuPC 4000 & 2 & 2 & 2 & 2 & 2 & 2 & 2 & 2 & 2 \\
Komatsu PC2000 & 0 & 0 & 0 & 0 & 0 & 1 & 1 & 1 & 1 \\
Komatsu PC1250 & 1 & 1 & 1 & 1 & 1 & 1 & 1 & 1 & 1 \\
\hline
\end{tabular}

Table 14. Thickness comparison of temporary hauling road layers

\begin{tabular}{cccc}
\hline \multirow{2}{*}{ Layer } & \multirow{2}{*}{ CBR } & \multicolumn{2}{c}{ Z_ESWL_THICKNESS $(\mathrm{m})$} \\
\cline { 3 - 4 } & & HD 785-7 & HD 1500-7 \\
\hline sub-grade & $4 \%$ & - & - \\
sub-base & $6 \%$ & 0.337 & 0.422 \\
base & $40 \%$ & 1.133 & 1.407 \\
\hline
\end{tabular}

Table 15. Thickness comparison of permanent hauling road layers

\begin{tabular}{cccc}
\hline \multirow{2}{*}{ Layer } & \multirow{2}{*}{ CBR } & \multicolumn{2}{c}{ Z_ESWL_THICKNESS $(\mathrm{m})$} \\
\cline { 3 - 4 } & & HD785-7 & HD1500-7 \\
\hline sub-grade & $4 \%$ & - & - \\
sub-base & $15 \%$ & 0.871 & 1.089 \\
base & $40 \%$ & 0.351 & 0.434 \\
Surface & $>80 \%$ & 0.248 & 0.306 \\
\hline
\end{tabular}

\section{Geometry Design of Hauling Road}

It is critical importance to design an efficient haul road. (Baek and Choi, 2017). The models developed to optimize haul road grades are part of importance in complementing the productivity analysis (Navarro Torres et al., 2019). The changes in loading equipment also affected the geometry design of hauling roads, such as the width of straight road, the width of the turn, super elevation, cross slope, and safety berm. The following below is changes to the geometry design of the hauling road:
Width on a straight road $\quad: 22 \mathrm{~m}$

Minimum radius of bend $\quad: 34 \mathrm{~m}$

Front wheel drift angle $\quad: 10^{\circ}$

Width of the road at the bend : $23 \mathrm{~m}$

Super elevation $\quad: 0.04 \mathrm{~m} / \mathrm{m}$

High difference on super elevation : $0.92 \mathrm{~m}$

Cross Slope $\quad: 0.44 \mathrm{~m}$

Height of Safety berm $\quad: 2.2 \mathrm{~m}$

Width of Safety berm $\quad: 4.8 \mathrm{~m}$

Depth of Trench $\quad: 0.5 \mathrm{~m}$

Width of In-Pit Road Trench $: 1 \mathrm{~m}$

Width of Ex-Pit Road Trench $\quad: 1.5 \mathrm{~m}$

\section{Resequencing Due to Delay in Mud Loading}

The process of resequencing in West High wall is calculated based on the delay in mud loading process. Resequencing was simulated using Minex software, based on the official design of west high wall map. Software utilization is an important factor of productivity (Genc, Musingwini and Celik, 2016). The results of resequencing could simulate the direction on mining sequence progress, the location of loading equipment, and achieving coal production. Table 16 shows the prediction of achievable coal targets in 2018 with consideration towards delay in mud loading process. Results of resequencing indicates that overburden target is achieved with $0 \%$ deviation, while coal production missed the target with 505,833 tons or $12 \%$ under the target. 
Delay Effect of Mud Loading to the Open Pit Design in Terms of Meeting ... Karel L. Warda et al.

Table 16. Production comparison after resequencing due to delay

\begin{tabular}{ccrrrc}
\hline Month & Product & \multicolumn{1}{c}{ Plan } & Resequencing & \multicolumn{1}{c}{ Dev. } & $\%$ \\
\hline \multirow{2}{*}{ April } & OB & 2.806 .467 & 2.798 .072 & -8.394 & 0 \\
& Coal & 258.504 & 257.731 & -773 & 0 \\
\hline \multirow{2}{*}{ May } & OB & 3.359 .181 & 3.352 .476 & -6.705 & 0 \\
& Coal & 207.988 & 217.017 & 9.029 & 4 \\
\hline \multirow{2}{*}{ June } & OB & 3.248 .025 & 3.241 .542 & -6.483 & 0 \\
& Coal & 307.874 & 303.355 & -4.519 & -1 \\
\hline \multirow{2}{*}{ July } & OB & 4.329 .261 & 4.316 .312 & -12.949 & 0 \\
& Coal & 353.206 & 349.565 & -3.641 & -1 \\
\hline \multirow{2}{*}{ August } & OB & 3.497 .411 & 3.490 .430 & -6.981 & 0 \\
& Coal & 461.720 & 449.057 & -12.664 & -3 \\
\hline \multirow{2}{*}{ September } & OB & 4.182 .619 & 4.174 .271 & -8.349 & 0 \\
& Coal & 652.060 & 652.122 & 62 & 0 \\
\hline \multirow{2}{*}{ October } & OB & 3.905 .545 & 3.893 .864 & -11.682 & 0 \\
& Coal & 943.075 & 513.008 & -430.067 & -46 \\
\hline \multirow{2}{*}{ November } & OB & 3.563 .164 & 3.556 .052 & -7.112 & 0 \\
& Coal & 537.776 & 445.621 & -92.156 & -17 \\
\hline \multirow{2}{*}{ December } & OB & 3.470 .020 & 3.459 .641 & -10.379 & 0 \\
& Coal & 636.785 & 665.682 & 28.897 & 5 \\
\hline \multicolumn{2}{c}{ Total OB } & 32.361 .694 & 32.282 .661 & -79.033 & 0 \\
\hline \multicolumn{2}{c}{ Total Coal } & 4.358 .990 & 3.853 .157 & -505.833 & -12 \\
\hline
\end{tabular}

\section{West High Wall Redesign}

Alternative is required due to unachieved target in coal production with 505,833 tons. One alternative was to change the design in the area. Changes in design can be made in areas where coal with a low stripping ratio is present, while at the same time did not significantly affect the hauling distance. The yellow area (Figure 8 ) shows the design on area with a low stripping ratio in 2019. The area was chosen because it had a potential coal seam, similar to untakeable coal seam which could not be taken due to delay in mud loading. In carrying out mining activities in the area, changes in hauling roads were needed; such as changing the hauling road design to the south. On the other hand, the design changes also could affect the medium-term planning. Through calculations on Minescape software, the changes in area design resulted in overburden of $1,787,205 \mathrm{BCM}$ with coal of 545,322 tons. The changes also had an impact on the addition of hauling distances of $87 \mathrm{~m}$. These conditions indicate that changes in design were worth considering to meet the production targets.

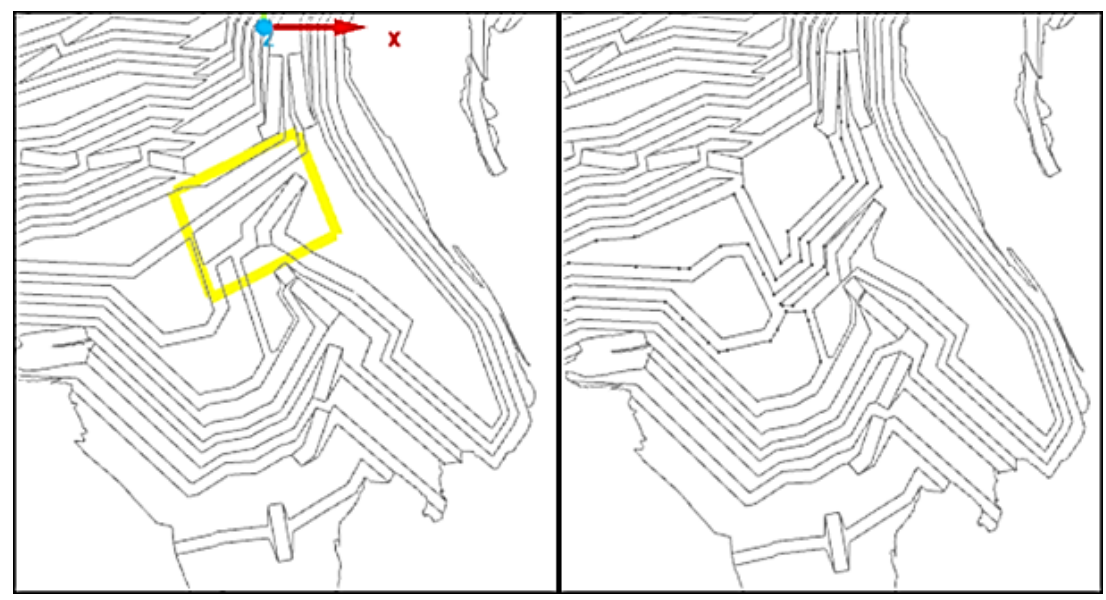

Figure 8.Design and redesign of West High wall in 2018 


\section{Resequencing Result of West High Wall Redesign}

The results in design changes were processed by re-conducting the process using Minex software, based on the redesign map in 2018. The results of resequencing, in Table 17, show an excessive coal production of 10,067 tons, thus exceeding the production target.

\section{CONCLUSION AND SUGGESTION}

The delay in the mud loading process was caused by various factors in both internal and external factors. The results of the analysis with statistical and non-statistical approach shows three reasons which impacted mud loading delays. First, the difference in value assumption of the swell factor at the planning stage with actual conditions had an impact of $9.24 \%$ on unachieved mud production target. Second, a sub-optimal loading cycle of backhoes and shovels had resulted in unachieved mud production target of $7.77 \%$. Then, there was excessive working time loss due to increased stand-by hours (rain and slippery conditions), pause hours (praying and toilet breaks), as well as delay in operating hours (refueling, equipment light maintenance, UA waiting time, and front/road/disposal preparations) resulting in unachieved production of $41.33 \%$.

The completion of the $A B C$ sump mud loading process was expected to be completed on 31 May 2018 (31 days late), while BCD sump on 3 August 2018 (64 days late).

The delay in loading process of the two intermediate sumps resulted in a change in the positioning plan, the number and type of mechanical equipment in overburden production activity, changes in geometry design and hauling road construction, as well as unachieved coal production target at the end of 2018 of 505,833 tons.

The impact of unachieved of the coal production target in 2018 was handled by making changes to the pit design in 2018, so that coal production could reach the predetermined target.

Table 17. Production comparison after redesign

\begin{tabular}{lcrrrc}
\hline \multicolumn{1}{c}{ Month } & Product & \multicolumn{1}{c}{ Plan } & Resequencing & \multicolumn{1}{c}{ Dev. } & $\%$ \\
\hline \multirow{2}{*}{ April } & OB & 2.806 .467 & 2.798 .072 & -8.394 & 0 \\
& Coal & 258.504 & 270.941 & 12.437 & 5 \\
\hline \multirow{2}{*}{ May } & OB & 3.359 .181 & 3.352 .476 & -6.705 & 0 \\
& Coal & 207.988 & 309.168 & 101.180 & 49 \\
\hline \multirow{2}{*}{ June } & OB & 3.248 .025 & 3.241 .542 & -6.483 & 0 \\
& Coal & 307.874 & 368.114 & 60.240 & 20 \\
\hline \multirow{2}{*}{ July } & OB & 4.329 .261 & 4.316 .312 & -12.949 & 0 \\
& Coal & 353.206 & 480.252 & 127.046 & 36 \\
\hline \multirow{2}{*}{ August } & OB & 3.497 .411 & 3.490 .430 & -6.981 & 0 \\
& Coal & 461.720 & 442.592 & -19.129 & -4 \\
\multirow{2}{*}{ September } & OB & 4.182 .619 & 4.174 .271 & -8.349 & 0 \\
& Coal & 652.060 & 598.366 & -53.695 & -8 \\
\hline \multirow{2}{*}{ October } & OB & 3.905 .545 & 3.893 .864 & -11.682 & 0 \\
& Coal & 943.075 & 596.758 & -316.318 & -34 \\
\hline \multirow{2}{*}{ November } & OB & 3.563 .164 & 3.556 .052 & -7.112 & 0 \\
& Coal & 537.776 & 548.696 & 10.919 & 2 \\
\hline \multirow{2}{*}{ December } & OB & 3.470 .020 & 3.459 .641 & -10.379 & 0 \\
& Coal & 636.785 & 754.171 & 117.385 & 18 \\
\hline Total OB & & 32.361 .694 & 32.282 .661 & -79.033 & 0 \\
\hline Total Coal & 4.358 .990 & 4.369 .057 & 10.067 & 0 \\
\hline
\end{tabular}


Based on the Energy and Mineral Resources Ministerial Decree Number 1827/K/30/MEM/ 2018 , for mud loading process planning, it is necessary to consider swell factors based on field testing and conduct geotechnical studies on mud disposal facilities, so that no dumping distance changes occur due to unpreparedness in mud disposal. Selected special loading and hauling equipment in accordance with the mud loading process, add loading or hauling equipment to create a fleet match, planning the refueling process and maintenance of light equipment, and preparing support equipment for front preparation, which is necessary to reduce the excessive loss of working time and at the same time achieve performance values

Further research needs to consider the factors of maintenance schedule and sensitivity in excessive loss of working time due to rain and slippery condition on stand-by hours, the information on possible delay and completion in mud loading process then can be obtained by considering these factors. Further research needs to consider the impact of changes in plan and design toward $X Y Z$ pit medium-term mining plan.

The study concludes that the availability of low stripping ratio in the cutback area for facilitating changes in design, especially in mid-term plan and design process, is necessary when the mining sequence progress is delayed.

\section{ACKNOWLEDGEMENTS}

The authors would like to send a gratitude to the people who provided help towards the completion of this study, namely my parents, Mining Engineering Program at UPN "Veteran" Yogyakarta and lastly the company, PT. Al Tbk, for the assistance in providing data related to this research. Hopefully, this research is beneficial for the company, and other researchers as an insight in the mining.

\section{REFERENCES}

Baek, J. and Choi, Y. (2017) "A new method for haul road design in open-pit mines to support efficient truck haulage operations," Applied Sciences, 7(7), p. 747. doi: 10.3390/app7070747.
Blom, L. M., Burt, C. N., Lipovetzky, N., Pearce, A. R. and Stuckey, P. J. (2016) "Scheduling tools for open-pit mining operations." The University of Melbourne, Australia.

Burt, C. N. and Caccetta, L. (eds.) (2018) Equipment selection for mining: With case studies. Cham: Springer International Publishing (Studies in Systems, Decision and Control). doi: 10.1007/978-3-319-76255-5.

Caccettta, L. and Hill, S. P. (1999) "Optimization techniques for open pit mine scheduling," in Oxley, L. (ed.) MODSIM 1999 International Congress on Modelling and Simulation. New Zealand: Modelling and Simulation Society of Australia and new Zealand Inc., pp. 895-900.

Caterpillar (2013) Surface mine primary loading tool: Selection guide. Caterpillar.

Caterpillar (2017) Caterpillar performance handbook. 47th ed. Illinois: Caterpillar.

Darling, P. (2011) SME mining engineering handbook. 3rd ed. Society for Mining, Metallurgy, and Exploration.

Genc, B., Musingwini, C. and Celik, T. (2016) "Estimating mine planning software utilization for decision-making strategies in the South African coal mining sector," Journal of the Southern African Institute of Mining and Metallurgy, 116(3), pp. 221-227. doi: 10.17159/24119717/2016/v116n3a2.

González, H. and Morales, N. (2019) "Optimal selection and assignment of loading equipment for the compliance of an openpit production plan," in Proceedings of the 27th International Symposium on Mine Planning and Equipment Selection MPES 2018. Cham: Springer International Publishing, pp. 245-254. doi: 10.1007/978-3-319-99220-4_20.

Hustrulid, W. A., Kuchta, M. and Martin, R. K. (2013) Open pit mine planning and design. 3rd ed. London: CRC Press.

Ibrahimov, M., Mohais, A., Schellenberg, S. and Michalewicz, Z. (2014) "Scheduling in iron ore open-pit mining," The International Journal of Advanced Manufacturing Technology, 72(5-8), pp. 1021-1037. doi: 10.1007/s00170-0145619-8.

Lambert, W. B., Brickey, A., Newman, A. M. and Eurek, K. (2014) "Open-pit blocksequencing formulations: A tutorial," 
INDONESIAN MINING JOURNAL Vol. 23, No. 2, October $2020: 67$ - 82

Interfaces, 44(2), pp. 127-142. doi: 10.1287/inte.2013.0731.

Manyele, S. V. (2017) "Investigation of excavator performance factors in an open-pit mine using loading cycle time," Engineering, 09(07), pp. 599-624. doi: 10.4236/eng.2017.97038.

Mkhatsahwa, S. V. (2009) "Optimization of the loading and hauling fleet at Mamatwan open pit mine," The Journal of The Southern African Institute of Mining and Metallurgy, 109(4), pp. 223-232.

Navarro Torres, V. F., Ayres, J., Carmo, P. L. A. and Silveira, C. G. L. (2019) "Haul productivity optimization: An assessment of the optimal road grade," in Proceedings of the 27th International Symposium on Mine Planning and Equipment Selection - MPES 2018. Cham: Springer International Publishing, pp. 345-353. doi: 10.1007/978-3-31999220-4_28.
Nelis, G., Morales, N. and Widzyk-Capehart, E. (2019) "Comparison of different approaches to strategic open-pit mine planning under geological uncertainty," in Proceedings of the 27th International Symposium on Mine Planning and Equipment Selection - MPES 2018. Cham: Springer International Publishing, pp. 95-105. doi: 10.1007/978-3-31999220-4_8.

Pasch, O. and Uludag, S. (2018) "Optimization of the load-and-haul operation at an opencast colliery," Journal of the Southern African Institute of Mining and Metallurgy, 118(5), pp. 449-456. doi: 10.17159/2411-9717/2018/v118n5a1.

Thompson, R. J. (2015) Principles of mine haul road design and construction. V2.0.15. Australia: Thompson.

Zaki, M. (2018) Kajian teknis pemindahan lumpur di area penambangan Muara Tiga Besar Selatan PT. Bukit Asam (Persero) Tbk. Universitas Syiah Kuala. 